\title{
Environmental Leprosy Through the Lens of Waste Disposal and Management in Bamenda II Municipality, Northwest-Cameroon
}

\author{
Gideon Samba and Japhet Chianebeng Kuma
}

\section{ABSTRACT}

\begin{abstract}
Waste, whether in solid or liquid form are indispensable parts of human activity. They emanate from man's productive activities or as a by-product of the materials consumed by man. Man appears not able to deal sufficiently with this waste even though the natural environment is the recipient of this waste. In the Bamenda II municipal council, like in some other towns of Cameroon, solid waste dumping is indiscriminate and has exerted negative effect on the environment. This study termed environmental leprosy through the lens of waste disposal in Bamenda II had as objectives to investigate solid waste disposal methods as drivers to environmental leprosy, assess the relationship between household's attitude and practices of indiscriminate solid waste disposal and identify measures that can be taken to eliminate environmental leprosy in Bamenda II Municipality. To achieve these objectives, data were obtained through primary and secondary sources using a mixed design method of inquiry which combines both quantitative and qualitative approaches to explore data on solid waste dumping in the study matrix. Purposive and systematic sampling techniques were employed for the sample population of 156 using Miller \& Brewer [17] sample determination method. The data generated were analyzed using descriptive statistics with the help of SPSS logistic version 20. Results from the analysis showed that indiscriminate solid waste dumping have exerted negative effects on the environment thus environmental leprosy. The study also indicated that households attitude have also contributed greatly to indiscriminate sold waste dump in Bamenda II. The study therefore strongly recommends the Ministry of Health and that of Environment at the national and regional levels, to both agree on responsibilities for appropriate waste management policies that could be implemented in all regional municipal councils.
\end{abstract}

Keywords: Environmental leprosy, waste disposal, management, Bamenda II, Municipality.
Published Online: November 23, 2020

ISSN: $2684-446 \mathrm{X}$

DOI : $10.24018 /$ ejgeo.2020.1.6.86

Gideon Samba*

Department of Geography, The University of Bamenda, HTTC,

Cameroon.

(e-mail: sam_deon@yahoo.fr)

Japhet. C. Kuma

Department of Geography and Planning, The University of Bamenda, Cameroon. (e-mail: chianebeng@ yahoo.com)

*Corresponding Author

\section{INTRODUCTION}

Solid wastes have become an environmental stressor disrupting the relationship between man and his environment in most parts of the developing world. African Cities and towns are no safer places from unwanted items ranging from plastics, papers, tine and metals, organic household waste as well as hazardous utensils which litters around on the urban environment. Roads and marketplaces are piled up and doted all over with patches of waste deposit of all sorts making the living environment looks leprosylike. Open, unfettered dumps are still the most used methods of waste discarding in most developing countries. The waste disposal option in Nigerian cities is principally open dumping followed closely by open burning [1], [2]. Other disposal options are open dumping, open burning, and composting [1]-[3]. The prescribed treatment of waste on the disposal site is usually open burning to reduce quantities [3].

In Cameroon as in other Sub-Saharan African countries, rising population statistics and urbanization are driving an exponential increase in the production of household waste. Urban household solid waste, according to [4], [5] are those wastes from human, animal, domestic and economic activities in the household that are normally discarded as useless or unwanted.

Household solid waste generation and disposal have become an increasing and contentious problem in the urban environment due to swelling population statistics, high density, urbanization, industrialization, the inefficiency of the collecting systems, and lack of political will on the part of the governments. A person generates $0.49 \mathrm{~kg}$ of waste a day, with households accounting for $90 \%$ of the urban waste [6]. The composition of waste suggests a content of over forty per cent recycling rate. In cities like Bamenda, 
Kumba and Buea where political instability persists for some time now, heaps of household garbage mixed with tine and metals are found along street junctions and marketplaces while some are dump in open drains and gutters. This state of affairs is consistent with waste generated in developing countries such as Cameroon, Ghana, Jordan, Nigeria and the Palestine [7]-[11].

In this study, the researcher considers the human environment as being attacked by leprosy through indiscriminate waste materials arising from operational activities which litters everywhere on the urban landscape. Because of this, the urban environment is becoming sick, we now witness deteriorating environmental conditions, the urban ecosystem is malfunctioning because of plastics and hazardous waste disposal of all sorts, even the urban hydrological network is suffering from industrial and commercial waste dumps jeopardizing the health of aquatic life. Humans have always regarded leprosy as a sickness which attacks the human body with rashes and blistering through the whole body. To medical experts, it is a chronic infectious disease which attacks the human skin caused by Mycobacterium leprae [12].

This study therefore considers the living environment as being attacked by leprosy through the lens of solid waste disposal. The urban environment today presents chronic ugly looks with mounting heaps of rotten garbage along urban streets, nylon, polythene bags, metals, and bottles. All these wastes are gradually and slowly changing the facelook of man's environment: rashes, lumps on the landscape and waste traps in rivers. One may not be wrong to say the environment has been attacked by 'leprosy'. A clear example is the Cameroons urban environment characterized by uncollected and improperly disposed wastes which poses serious risks to public health and the environment. The prevalence of parasites, tetanus, malaria, hookworm, cholera and diarrhoea in most African countries is attributed to the unsanitary conditions of the environment caused by waste being simply strewn around cities, villages, and other habitable areas [13]. In some African cities, incidents of flash floods, water pollution and littered landscapes have been credited to poor waste management practices [14], [15].

This paper tagged environmental leprosy through the lens of waste disposal is geared towards raising awareness on the issues of indiscriminate dumping of waste on the Bamenda II town environment. The urban environment is losing its quality and beauty, becoming unfriendly and even scares people from passing along certain streets. If this undiscerning dumping continues, there are fears of possibilities of increasing outbreaks of air borne, as well as water borne diseases in a not far away future.

\section{STUdY AREA}

Bamenda II subdivision is located in the North West Region of Cameroon, precisely in Mezam Division. The precise location of Bamenda II falls geographically, between longitude $10^{\circ}-08^{\prime}$ to $10^{\circ}-12^{\prime}$ East and latitude $05^{\circ}-55^{\prime}$ to $6^{\circ}-10^{\prime} \mathrm{N}$ and covers a surface area of about $79.23 \mathrm{~km}^{2}$.
Bamenda II is bordered to the north by Bafut as its neighbouring boundary, by Bamenda I and Bamenda III to the East, Bali and Mbengwi to the West, and finally Santa to the Southern part.

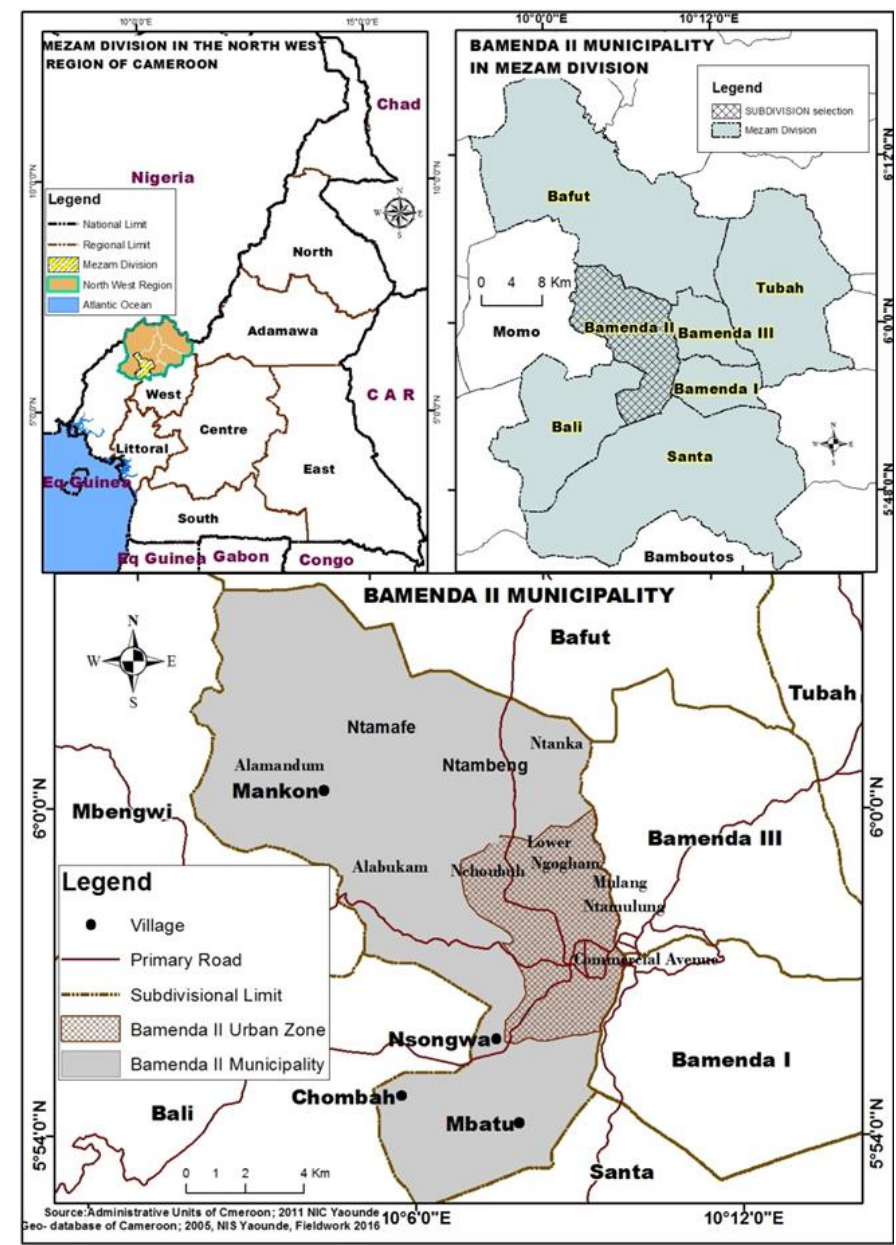

Fig. 1. Location of Bamenda II in Mezam Division, Cameroon [16].

\section{Methodology}

Some key issues within the study included the haphazard manner by which household waste is disposed as well as the capacity of its management by the Bamenda II municipal authorities. Data collection was therefore tilted towards this domain and to do that properly, structured questionnaires were developed and administered to some 156 selected households using the Miller and Brewer [17] sample determination method at 0.08 error margin. The study adopted the systematic random sampling techniques to administer the instrument and the administration gave a $100 \%$ response rate because the survey questionnaires were administered based on direct household-to-household visit.

The study also made use of secondary sources of data which covered the review of relevant literature on the concept, processes and strategies of solid waste management, best practices and models that promote waste reduction, reuse and recycling activities in Bamenda II. These were obtained from libraries, journals, textbooks, and the internet. 
The raw data were analyzed using descriptive and inferential statistics and summarized into tabular format. The Linear regression model was utilized at a significance level of 0.05 to analyse and predict the values of the dependent and independent variables, (household's attitude and practices towards indiscriminate solid waste disposal). The analyses were conducted using SPSS version 20. The statistical tools such as frequency (f), percentage (\%), average $(\mathrm{x})$, standard deviation, range, coefficient of correlation and $\mathrm{F}$ test were applied for analysis of the data as per Snedecor and Cochran [18].

\section{RESUlTS AND DisCUSSION}

\section{A. Types of Household Waste Generated in Bamenda II}

The generation of municipal solid waste have kept on increasing and is expected to double in the nearest future if management measures are not put in place by the municipal authorities. As of the moment this research is conducted, solid waste dumps are rampant in the city and gradually transforming the beauty of the city to a leprosy-liked environment. It's nevertheless understandable that the present socio-political crisis has not helped matters, as more streets and road junctions have become spaces of solid waste dumping ground and deteriorating environmental quality.

Field survey and observation data in Bamenda II revealed a good number of solid waste types as presented on Table 1. Of the total wastes produced, household garbage was noticed to be dominant at $100 \%$. Cartoons and nylon papers were also observed to be types of solid wastes produced within the study matrix, representing $98.7 \%$ and $94.2 \%$ of total wastes generated.

TABLE I: TYPES OF SOLID WASTE PRODUCED IN BAMENDA II

\begin{tabular}{cccccc}
\hline Types of & \multicolumn{3}{c}{ Frequency of responses } & \multirow{2}{*}{ Effective } \\
\cline { 2 - 4 } waste & Agreed & $\%$ & disagreed & $\%$ & \\
\hline $\begin{array}{c}\text { Polythene } \\
\text { bags }\end{array}$ & 141 & 91.0 & 14 & 9.0 & 156 \\
Plastic bottles & 143 & 91.7 & 13 & 8.3 & 156 \\
Nylon papers & 147 & 94.2 & 9 & 5.8 & 156 \\
Households & 156 & 100.0 & 00 & 00 & 156 \\
garbage & 109 & 69.9 & 47 & 30.1 & 156 \\
Iron rots & 154 & 98.7 & 2 & 1.3 & 156 \\
Cartoon & 139 & 89.1 & 17 & 10.9 & 156 \\
papers & 137 & 87.8 & 19 & 12.2 & 156 \\
Broken bottles & & & & & \\
Others (food & & & &
\end{tabular}

Moreover, other types of household wastes dumped indiscriminately around the urban environment include polythene bags $(91.0 \%)$; plastic papers $(91.7 \%)$; broken bottles $(89.1 \%)$; other food waste mainly vegetable and meat materials, leftover food, eggshells with bulk of it produced at market places was considered as type of solid waste at $(87.8 \%)$; and iron rots $(69.9 \%)$.

\section{B. Methods of Waste Disposal in Bamenda II}

Unlike in the past before the advent of the socio-political crisis in 2016, waste disposal in Bamenda city and especial in Bamenda II council was largely controlled by HYSACAM (a French acronym meaning hygiene and health in Cameroon). The Bamenda City Council (BCC) deposited trash cans at marketplaces and at road junctions for household waste deposit and easy collection by the HYSACAM. But as from 2017, with heighten insecurity in the City; it became very difficult and constraining for households in the city to dispose of their solid waste in trash cans. Things worsened as HYSACAM workers abandoned assiduity in the discharge of their functions of solid waste clearance from dustbins. As a consequence, households in Bamenda II had no option than disposing their solid wastes on open spaces, vacant plots, in streams and rivers, and or burning on the streets, as such changing the face look of the city to a dusty, dirty, scary landscape, dotted with solid wastes everywhere.

TABLE 2: WASTE DISPOSAL METHOD BY SURVEYED HOUSEHOLDS IN BAMENDA II

\begin{tabular}{cccccc}
\hline Method of & \multicolumn{4}{c}{ Frequency of responses } & \multirow{2}{*}{ Effective } \\
\cline { 2 - 5 } waste disposal & Agreed & $\%$ & Disagreed & $\%$ & \\
\hline Open space & 142 & 91.0 & 14 & 9.0 & 156 \\
Vacant plots & 132 & 84.6 & 24 & 15.4 & 156 \\
$\begin{array}{c}\text { Public trash } \\
\text { cans }\end{array}$ & 44 & 28.2 & 112 & 71.8 & 156 \\
$\begin{array}{c}\text { Stream drainage } \\
\text { deposit }\end{array}$ & 149 & 95.5 & 7 & 4.5 & 156 \\
$\begin{array}{c}\text { Burning } \\
\text { Streets/road } \\
\text { junctions }\end{array}$ & 151 & 96.8 & 5 & 3.2 & 156 \\
\hline
\end{tabular}

Table 2 represents survey data from household's expressing methods of waste disposal in Bamenda II. According to the survey, $91.0 \%$ of the respondents acknowledged they disposed of their households' waste in open spaces not designed by the municipal council; only $9.0 \%$ of this category do not throw waste in open dumps. Again, $84.6 \%$ of the surveyed indicated that their means of waste disposal was on vacant plots. A clear finding from the research is that waste disposal through public trash cans in the city recorded the lowest frequency rate with $28.2 \%$ of residents accepting that it is their means of waste disposal. This is actually an indication that HYSACAM services which is one of the government agencies set out to keep Bamenda clean has collapsed or is less functional given the present state of things in Bamenda II.

Streams drainage deposit $(95.5 \%)$ was further considered as one of the easy ways to discharge solid waste especially those inhabitants around Food Market, City Chemist and Old Town precisely at Bum quarter. The streams in these places have become dumping grounds for solid waste disposal. A greater majority of surveyed respondents burnt their waste; this was acknowledged by $96.8 \%$ of the households. Finally, $99.4 \%$ of households investigated throw their waste on the streets and road junctions. 


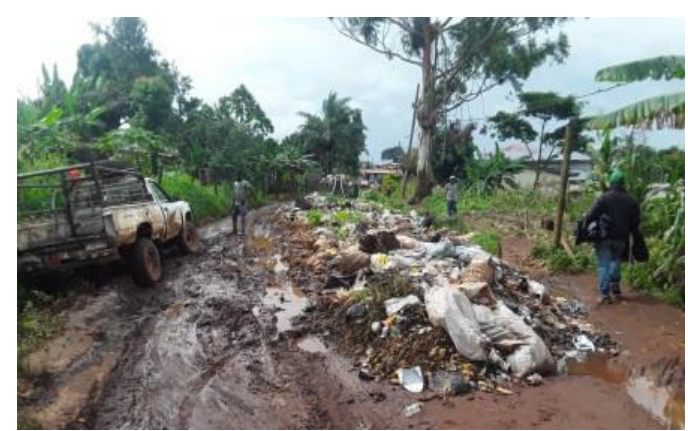

Fig. 1. Indiscriminate and open spaces waste dumps in Bamenda II.

Le Bien street Ntarinkon blocked by open households' waste dump, rendering accessibility by vehicles and pedestrians difficult.

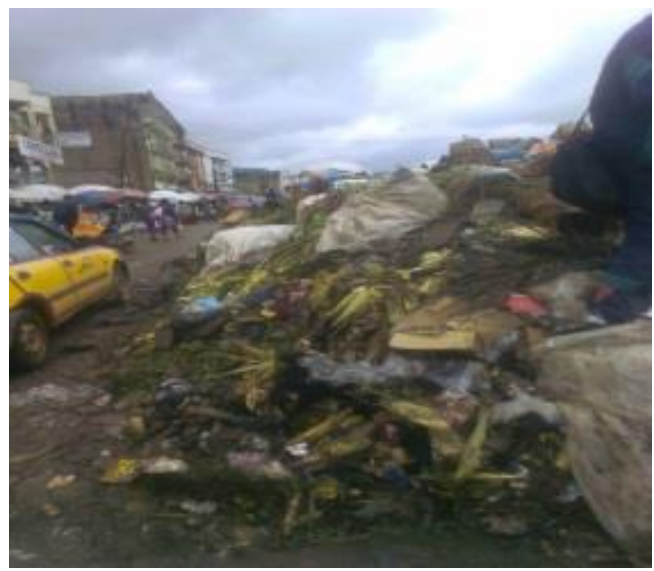

Fig. 2. Indiscriminate waste dumps at Food Market, Bamanda II.

\section{Waste Disposal as Drivers of Environmental Leprosy}

Indiscriminate waste dumping in the Bamenda II municipal council has been described by many as improper and leading to a dirty and fragile environment. The rate of solid waste dumping on streets, streams and unauthorized areas has increased to a devastating and uncontrollable rate such that the living environment is equated to someone with leprosy as the face look of the urban environment scape of Bamenda II has changed. Table 3, designed in a four point likert scale, describes the perception of the surveyed households in Bamenda II regarding waste disposal as drivers to environmental leprosy.

TABLE 3: PERCEPTION OF WASTE DISPOSAL AS DRIVERS TO ENVIRONMENTAL LEPROSY

\begin{tabular}{ccccccccc}
\hline \multicolumn{1}{c}{ ENVIRONMENTAL LEPROSY } \\
\hline S/N & SA & A & Total & $\%$ & D & SD & Total & $\%$ \\
\hline 1 & 116 & 31 & 147 & 94.3 & 6 & 3 & 9 & 5.7 \\
2 & 89 & 53 & 142 & 91.0 & 14 & 00 & 14 & 9.0 \\
3 & 70 & 63 & 133 & 85.3 & 20 & 3 & 23 & 14.7 \\
4 & 78 & 67 & 145 & 92.9 & 5 & 6 & 11 & 7.0 \\
5 & 84 & 61 & 145 & 92.9 & 11 & 00 & 11 & 7.0 \\
6 & 83 & 53 & 136 & 87.2 & 20 & 00 & 20 & 12.8 \\
7 & 97 & 46 & 143 & 91.7 & 13 & 00 & 13 & 8.3 \\
8 & 110 & 36 & 146 & 93.7 & 7 & 3 & 10 & 6.3 \\
\hline
\end{tabular}

Note: SA=Strongly Agreed; $\mathrm{A}=$ Agreed; $\mathrm{D}=$ Disagreed; $\mathrm{SD}=$ Strongly Disagreed.

The findings on Table 3 reveal the perception of sample respondents on waste disposal as drivers to environmental leprosy perceived through indiscriminate waste dumping which leads to very dirty and eyesore environment. The survey and interview data confirmed that $94.3 \%$ of households perceived indiscriminate wastes dumping a major cause for dirty urban environments. $5.7 \%$ of the remaining sample households were in disagreement with this perception. It was also perceived that solid waste dump causes loss to environmental biodiversity leading to environmental degradation. This perspective was accepted by $91.0 \%$ while $9.0 \%$ were against. It was ascertained by $85.3 \%$ of sample respondents that indiscriminate waste dump creates negative environmental impacts such as infectious disease which relates to environmental leprosy, only $14.7 \%$ respondents disagreed with this fact.

The survey further indicates the perception of $92.9 \%$ sample respondents in Bamenda II who admitted that the land and water pollution which causes serious environmental nuisance in the study area is directly linked to heaps of open waste dumps in the municipality.

The opinion of $7.0 \%$ of sample respondents was less counted. Still in the survey, $87.2 \%$ respondents positively reacted on the fact that indiscriminate discard of polythene bags especially around the Food market and Ntarinkon market environs; generate a lot of aesthetic nuisance with negative effect on environmental wellbeing.

It is also noted in the research finding as presented on table 4 that haphazard waste dumping leads to rapid environmental degradation which brings about adverse effect on the general sustainability and liveability of urban life, widespread of germs and diseases, extinction of aquatic lives due to water toxicity and acidification. $91.7 \%$ survey respondents supported this point while $8.3 \%$ refuted. The study's finding was equally ascertained by 93.7\% sample households that waste dump scares people from passing by certain areas of the urban environment of Bamenda II. The research, in addition observed that some quarter roads within the Bamenda II municipality were blocked with solid waste which rendered the road inaccessible.

\section{Proposed Sustainable Measures of Waste Management in Bamenda II}

Solid waste management remains the most urgent concern and task for urbanizing towns like that of Bamenda II. During the study, a number of measures were proposed by sample respondents amongst which included the creation of sanitary inspection, clean-up campaign intensification, employment of road cleaners by the municipal council and the creation of awareness programs to sensitize citizens on the dangers of rampant solid waste dump on the environment.

From the results as presented on the Fig. 3, the scores were $100.0 \%$ response rate for those who suggested the creation of inspection teams and clean-up campaigns. The households claimed that if this is put in place, indiscriminate dumping of solid waste in the municipality will drastically reduce. 


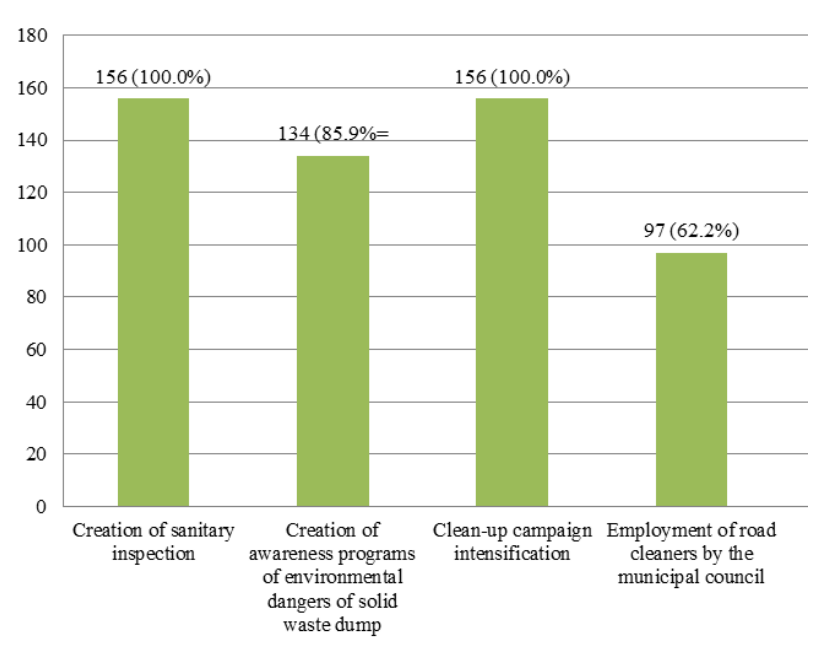

Fig. 3. Propose measures to control indiscriminate solid waste dump in Bamenda II.

The finding also indicated an over whelming response form $85.9 \%$ survey residents supported the creation of awareness programs on the dangers of indiscriminate solid waste dumping on the environment. Those who suggested for the employment of road cleaners in the municipality constituted $62.2 \%$.

\section{CONCLUSION}

Indiscriminate solid waste disposal in Bamenda II municipal council is a serious issue because of the environmental stress and degradation these wastes brings. From the findings of this study, it was observed that indiscriminate dumping of solid wastes in Bamenda II led to negative environmental effects, health, and also people' attitude which will have multiplier effects on the inhabitants liveability of the area. Indiscriminate dump of solid waste causes infectious disease among people, contamination of food and water, air pollution, sharp objects which transforms the Bamenda II urban scape to look like an environment attacked by leprosy because of the dotted solid waste all over. It also serves as breeding sights for disease vectors. People's attitude such as refusal to pay waste management bills, laziness, and violation of rules on waste disposal has been described in this study as the effects and causes of indiscriminate solid waste dumping in Bamenda II which the researcher called environmental leprosy. While the Government has good intention to tackle the problem of environmental pollution within the city, it has a very low political will to back up its desire as the crisis deepened in the region.

\section{ACKNOWLEDGMENT}

We appreciate the support of Doris Lamnyam NJUH, NGONG Lois Fuen and Professor FOMBE Lawrence.

\section{REFERENCES}

[1] Dauda, M., and Osita, O.O., (2003). Solid waste management and reuse in Maiduguri, Nigeria. 29th WEDC International Conference towards the Millennium Development Goal, Abuja.

[2] Ogwueleka (2009), "Municipal Solid Waste Characteristics and Management in Nigeria. Iran J. Environ health Sci. Eng 2009 vol. 6 No 3 pp 173-180.

[3] Imam, A., Mohammed, B., Wilson, D., \& Cheeseman, C. (2008). Solid waste management in Abuja, Nigeria. Waste Management, 28(2), 468-472.

[4] Senkwe and Nwale (2001): Assessment of the Factors Influencing the Generation and Disposal of Urban Household Solid Waste in Africa: The Nigerian Perspective.

[5] Tchobanoglous, G., Theisen, H. and Vigil, S. (1993). Integrated Solid Waste: Engineering principles and management issues. McGraw-Hill Publishing company, USA.

[6] Solomon, U. U. (2009). The state of solid waste management in Nigeria. Waste management (New York, NY), 29(10), 2787.

[7] Okechukwu, O. I., Okechukwu, A. A. Noye-Nortey, H. and Owusu. A. (2012). "HealthPerception of Indiscriminate Waste Disposal - A Ghanaian Case Study." Journal of Medicine and Medical Sciences, 3 (3): 146-154.

[8] Oberlin, A. (2011). The role of households in solid waste management in East Africa capital cities. Dissertation. Wageningen: Wageningen Academic Publishers.

[9] Al-Khatib, Issam, A., Monou, M., Salam, A. F. Abu, Zahra., Shaheen, H. Q., Kassinos, D. (2010). Solid waste characterization, quantification and management practices in developing countries. A case study: Nablus district - Palestine, Journal of Environmental Management P.1131-1138.

[10] Fobil, J., May, J., \& Kraemer, A. (2010). Assessing the relationship between socioeconomic conditions and urban environmental quality in Accra, Ghana. International Journal of Environmental Research and Public Health, 7(1), 125-145.

[11] Wilson, D., Araba, A., Chinwah, K., \& Cheeseman, C. (2009). Building recycling rates through the informal sector. Waste Management, 29(2), 629-635.

[12] NLCP, (2014). National Leprosy Control Programme, Department of Public Health Ministry of Health: leprosy management guidelines for health workers 1st Edition.

[13] McMichael AJ. (2000). The urban environment and health in a world of increasing globalisation, issues for developing countries. Bull World Health Org;200(78):9.

[14] Palczynski RJ. (2002). Study on solid waste management options for Africa. Project Report for the African Development Bank Sustainable Development \& Poverty Reduction Unit. Abidjan, $C^{\wedge}$ ote d'Ivoire.

[15] Henry RK, Yongsheng Z, Jun D. (2006). Municipal solid waste management challenges in developing countries-Kenyan case study. Waste Manage ;26(1):92-100.

[16] CDP (2019). Council Development Plan of Bamneda II.

[17] Miller, R. L., \& Brewer, J. D. (2003). A-Z of Social Research. London: Longman.

[18] Snedecor, G.W. and Cochran, W.G. (1967) Statistical methods. 6th Edition, Ames, Lowa, the Lowa state University.

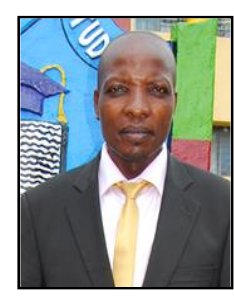

Dr. Gideon Samba is a Senior Lecturer at the Department of Geography, Higher Teacher Training College of the University of Bamenda-Cameroon. He holds a B.Sc., M.Sc. and M.Phil. degrees in Geography and Environmental planning from the university of Dschang-Cameroon and a $\mathrm{PhD}$ in Geography and Environmental Science (Forest ecology and management) From the University of Calabar-Calabar Nigeria since 2016.

Dr. Japhet Chianebeng Kuma is an Assistant Lecturer with the Department of Geography and Planning of the University of Bamenda, Cameroon. He holds a B.Sc., M.Sc. and M.Phil. degrees in Geography and Environmental Planning from the university of DschangCameroon and a PhD in Geography and Environmental Science (Urban Development Planning) From the University of Calabar-Calabar Nigeria since 2018. 